\title{
The Effect of Specific Learning Objectives on Children's Game-based English Learning
}

\author{
Yueqi Jia ${ }^{1, *, \dagger}$ \\ ${ }^{1}$ Suzhou University of Science and Technology, Suzhou, Jiangsu, China \\ ${ }^{*}$ Corresponding author. Email: ${ }^{1} 19200802111 @$ post.usts.edu.cn, \\ Those authors contributed equally.
}

\begin{abstract}
Aiming at the problems of classroom teaching students in children's second language acquisition, such as mobility, visualization and age-appropriate, this paper puts forward the classroom practice method of Scaffolding Teaching Method Based on ZPD educational thought, discusses the application of children's English game teaching in children's second language acquisition classroom teaching, and makes children more interested and motivated in mastering the second language through vocabulary practice Active second language acquisition learning, from the establishment of second language thinking mode as the internal purpose of the actual teaching behaviour. So as to make the teaching of children's second language acquisition achieve a more effective direction of teaching practice.
\end{abstract}

Keywords: Specific target, Child, Second language acquisition, Game teaching.

\section{INTRODUCTION}

Early childhood is a critical period for language learning and the best beginning period for second language acquisition. The development of second language acquisition education for children requires us to grasp the key period of language development of children. Children's second language acquisition education has formed a good education and teaching model in the process of years of specific teaching practice, and has more excellent teaching and research results and experience. With the popularization of second language acquisition education and the popularization and deepening of second language acquisition learning population, its younger age trend is becoming more and more obvious, However, the internal quality requirements, teaching effect demands and scientific operation reform needs of second language acquisition education for children, especially young learners, are becoming increasingly prominent. As the public attaches more and more importance to children's second foreign language acquisition, the promotion and development of relevant teaching research is also more urgent. Explore educational and teaching practice research to adapt to children's second language acquisition, and establish classroom teaching strategies and improvement schemes that pay more attention to comprehensive language literacy, language thinking construction, language teaching in fun and so on.

\section{THE CURRENT SITUATION OF CHILDREN'S SECOND FOREIGN LANGUAGE TEACHING AND THE IMPROVEMENT VALUE OF GAME TEACHING METHOD}

In recent years, children's parents and the public pay more and more attention to children's language learning, coupled with the increasingly heavy learning tasks of other age groups, which makes it inevitable for kindergartens to carry out English courses. At present, kindergarten teachers mostly learn the teaching methods of teachers who are responsible for the teaching of children of other age groups, and combine the characteristics of children themselves to adopt the method of game teaching which is most suitable for the age stage of children's development.

But in the actual teaching process, the game teaching method still has some shortcomings, the teaching effect is not very satisfactory. Therefore, in order to improve teaching efficiency and results, enable children to have better learning experience, and enable teachers to carry out teaching more smoothly and effectively, improving game teaching method is a very necessary and important task. ${ }^{[1]}$ 


\subsection{Analysis on the Current Situation of Classroom Education for Children's Second Language Acquisition}

The starting age of children's second language acquisition is gradually becoming younger. It puts forward more possibilities for the research and practice of second language acquisition according to children's actual development. Children's acceptance ability has its own characteristics. ${ }^{[2]}$

If the traditional classroom teaching method of second language acquisition is adopted, which is carried out by theoretical teaching, general teaching assistance and other methods, there will be many problems, such as low classroom teaching effect, students' loss of interest in language learning, language acquisition method does not conform to children's growth rules, and the formation of language thinking processing mode for children. ${ }^{[3]}$ It is urgent to improve and perfect by increasing the lively teaching methods of classroom teaching.

\subsection{Application Value and Significance of Game Teaching Method in Children's Second Foreign Language Classroom Teaching}

First of all, based on the regularity of children's mental development, children generally have a lively mentality of "seeking novelty, seeking activity, seeking interest and seeking difference". Games are conducive to catering to this mentality, creating a good atmosphere for teaching and learning, ${ }^{[4]}$ and enabling children to devote themselves to their second foreign language learning in an appropriate environment.

Secondly, it is conducive to the gamification of the teaching process, so that children can learn a second foreign language more actively in an excited state, better unlock wisdom, promote cognition, learning skills, enhance interaction, so as to make the results of foreign language learning more remarkable. ${ }^{[5]}$

Moreover, the application of game teaching can also help cultivate children's cooperative spirit. In classroom games, children usually need to cooperate to complete tasks. Game activities can not only improve their individual ability level, but also improve their cooperative ability. ${ }^{[6]}$

Last but not least, strict teaching methods will suppress children's nature. If teachers use game teaching method, they can return the dominant position of teaching to children, effectively improve the affinity of teachers, help to draw the distance between children and teachers, and equalize the status of both sides.

\subsection{Application and Practice of Game Teaching Method in Children's Second Foreign Language Classroom Teaching}

With the continuous reform and development of educational methods, game teaching method also began to be widely concerned by people. Can be seen from the practice, some of the children's attention and focus is not long-term effective concentration, therefore, the teacher must use good game teaching method in the practical teaching, and to do a good job of game teaching innovation, let the students into the relaxed game process, in this way can help children to achieve physical and mental satisfaction, help children enjoy learning.

Therefore, in order to improve the effect of game teaching method in children's second foreign language learning, teachers should make good use of game teaching method to attract children's attention and improve the teaching effect. ${ }^{[7]}$

\section{THE PRACTICAL VALUE OF THE PRACTICE OF GAME TEACHING METHOD IN CHILDREN'S SECOND FOREIGN LANGUAGE ACQUISITION TO THE REALIZATION OF SPECIFIC TEACHING OBJECTIVES}

Game teaching method in respect of the application of student learning, on the basis of characteristics and growth laws, to grasp the students' life demand, the organic combination of teaching activities and students' life, mining life of game elements, the optimization of auxiliary teaching innovation, and realize the cultivation of student's study interest, the maximum to promote the teaching effect of reinforcement. ${ }^{[8]}$ In short, the application purpose of game teaching method is to let students complete the learning of knowledge through playing and feel happy in learning.

Therefore, the application of game teaching method to children's second language teaching activities can realize the cultivation of students' interest in second language learning, let students actively participate in language game learning activities, reduce students' learning psychological pressure and resistance, and effectively ensure the overall learning effect of students.

Therefore, in the context of the new curriculum reform, in order to further highlight students' dominant position and realize the cultivation of students' interest in second language learning, teachers can reform and innovate classroom teaching activities with the help of the application of game teaching method, and promote the overall improvement of second language teaching quality with the help of game teaching method. ${ }^{[9]}$ 


\subsection{Effects of Classroom Play Teaching Method on Specific Learning Objectives of Second Language Classroom Teaching on Children's English Learning}

Learning objective is a direct factor affecting children's willingness to invest in learning, and learning objective is the specific direction of learners' learning. Introducing specific learning objectives into the application of classroom game teaching method is helpful for teachers to use game teaching method better. $[10]$

Specific learning objectives can help improve children's learning efficiency, let children focus on a specific task to be completed, let children focus on the classroom, so that second language learning becomes easier for children. At the same time, specific learning objectives can also effectively reduce the confusion caused by children's over-excitement in the classroom using game teaching method, help children develop good learning habits, and enable them to focus more on second language learning.

\subsubsection{Positive Effect of Game Teaching Method on Specific Learning Objectives in Classroom Teaching of Children's Second Foreign Language Acquisition}

Phonetics teaching is an important part of English teaching for children and one of the most important factors that restrict the development of children's comprehensive ability. Only by learning phonetics well, can we store the materials we have learned in the correct form in the brain and reproduce them in the correct form, so as to establish a sense of language and improve the ability to use language.

Through the teaching of situational games, it can help children to master "correct pronunciation" and "spelling" English words. The nature of the children is active and lively, for all things are full of curiosity, ${ }^{[11]}$ especially for the game, if we can combine the teaching content and vivid and interesting game, create a real English learning situation, not only can stimulate children's motivation to learn English, and let them in a relaxed and happy, with one, unity upward to study in the situations of the game. In this way, language learning objectives can be easily accomplished in the context of the game.

By using kindergarten situational games to create a language learning environment, children can acquire language sounds unconsciously and imperceptibly. Teachers can use the second foreign language they have learned in the game to communicate with children, so that children will unconsciously begin to acquire language pronunciation from listening.
3.1.2.The Development Space for the Game Teaching Method in the Classroom Teaching of Children's Second Foreign Language Acquisition to Achieve Specific Learning Objectives

Game teaching method can combine teaching with fun, so that children can complete learning tasks in games and achieve specific learning objectives proposed by teachers. In the second language learning class of children, the introduction of specific learning objectives into the game teaching method means that children are given specific tasks to complete in the game activities carried out in the second language learning class.

At present, most of the teaching games carried out in the classroom, especially the teaching games in the children's learning classroom, have the problem of unclear teaching purpose. This will affect the outcome of the teaching. Therefore, the realization of specific learning objectives in classroom teaching needs more research to promote its development. Attention should be paid to the formulation of specific learning goals, so that they can be more reasonable and more closely to the area of children's closest development, realistic and not out of the range of children's ability.

\section{2.the game teaching method in children's second language acquisition classroom teaching, the relationship between the ability to solve English word spelling problems, learning autonomy and interest in participating in games}

Spelling ability is an important factor to measure the effectiveness of children's second language learning. Through the detection of children's spelling ability before and after teaching games, the implementation effect of game teaching method can be reflected.

Game participation interest and learning autonomy are two important factors that affect children's learning results in teaching games. The research on the relationship between the three is also the research on how to better implement game teaching method in children's second language classroom.

The ability to solve English spelling problems, learning autonomy and interest in playing are all equally important for children's second language learning games. These three need us to pay enough attention to, cannot pay too much attention to a certain aspect or ignore a certain aspect, need to balance the three aspects comprehensively.

\subsubsection{The Relationship between Children's Ability to Solve Formal English Word Spelling Problems and Learning Autonomy}

In fact, autonomous learning refers to the behaviour 
that learners can recognize their knowledge, ability and other defects, actively adjust their learning strategies and efforts according to the requirements of learning ability and motivation, and independently learn knowledge, skills and ability. Although children's learning autonomy is not strong yet, they can also carry out autonomous learning in daily learning activities to a certain extent.

When children's learning autonomy is improved in the second language learning class, their learning outcomes will also be improved. The ability to solve the spelling problem of formal English words is closely related to children's classroom learning results. If children can perform well in classroom learning, their ability to solve the spelling problem of formal English words will also be greatly developed. After children's ability to solve the spelling problem of formal English words is developed, they will perform better in the second foreign language learning class, so they can get more encouragement and praise from teachers.

It can be seen that the ability to solve the spelling problem of formal English words and children's learning autonomy complement and promote each other.

\subsubsection{Make Good Use of the Game Learning} Method in Classroom Teaching of Children's Second Language Acquisition to Solve the Relationship between the Ability to Solve Formal English Word Spelling Problems and the Interest in Participating in the Game

In children's second language learning classes, it is often the case that children are not interested in participating in classroom learning because the content is too boring. The use of game teaching method can make the boring classroom for children become colourful.

Children's interest in participating in classroom games also determines their interest in classroom teaching. The greater children's interest in participating in classroom games, the greater their interest in learning a second language. The improvement of learning interest can make children more involved in learning, and they can learn more knowledge in the classroom, and the teaching effect of teachers is better.

And because of the improvement of learning effect, children's ability to solve the spelling problem of formal English words will therefore be improved. Therefore, if the game teaching method can be well used, children's interest in game and classroom participation can be improved together, and their ability to solve the spelling problem of formal English words can also be improved.
3.2.3.The Game Learning Method in Classroom Teaching of Children's Second Language Acquisition Realizes the Balance between Learning Autonomy and Interest in Game Participation

In the teaching games that adopt the game learning method in the classroom of children's second language learning, the interest of game participation is an important factor for children to actively participate in the classroom games.

Learning autonomy refers to the degree to which learners can actively learn, and in the second language classroom learning games, it refers to the degree to which children actively learn in the process of games. When children's interest in classroom games is improved, they can better engage in the game and pay more attention to the game content. By paying more attention to the content of the game, children are more active in understanding and absorbing the content of the game, which also improves their learning autonomy in classroom games, so that they can better learn in the game.

In the classroom of children's second language learning, there is a balanced relationship between learning autonomy and game participation interest.

\section{CONCLUSION}

The game teaching method plays a role in promoting children's second language learning, and also performs very well in classroom practice. Children can be more interested in learning a second language through game teaching and more focused on the classroom and the tasks they should complete.

At the same time, game teaching method can help the realization of specific teaching objectives, make teachers' classroom teaching objectives more clearly, and also contribute to the planning and implementation of teaching plans. ${ }^{[12]}$ The addition of specific teaching objectives can also make the game teaching method be better applied to the actual teaching links, so that the teaching objectives can be better understood and achieved by children.

Moreover, the introduction of specific learning objectives also provides a development direction for game teaching in the future. We can look forward to the future development of game teaching method in the classroom of children's second language learning.

On the other hand, we can also look forward to the application of game teaching method in a broader field of children's learning. 


\subsection{Analysis on the Current Situation of Classroom Education for Children's Second Language Acquisition}

Game teaching method is a brand-new teaching method in children's second language learning classroom. Different from the traditional indoctrination teaching method, game teaching method helps to enhance children's interest in second language learning, cultivate children's divergent thinking, and let children play in learning and learning.

Children are in the energetic, divergent thinking, lively and active, poor discipline stage, ${ }^{[13]}$ especially in the middle and large classes of children, often in the first five minutes of the class is still unable to concentrate. In the long run, this will not only affect students' learning results, but also hinder them to develop good learning habits. In view of this situation, teachers can introduce classroom teaching according to the teaching content by playing a little word reading game, so that students must devote themselves to the classroom. This not only helps students to listen carefully, but also helps students to understand.

At the same time, competition games are also very effective in creating a classroom atmosphere. Children are not afraid of difficulties and want to try new things in nature. Appropriate competition games can stimulate their desire to perform, so that they can actively participate in classroom teaching and activate the classroom atmosphere. Such as the word answer game can be very good to stimulate children's interest in learning and let them focus on the classroom.

\subsection{The Classroom Game Teaching Method of Children's Second Language Acquisition Has Positive Significance and Value for the Realization of Specific Teaching Objectives}

The development of children's learning ability is characterized by distinct age characteristics. The rapid speed of children's ability development and the transient critical period of their ability development make teachers need to use the most appropriate and efficient learning methods to teach children.

To achieve the specific learning goal of the second language, it is necessary to stimulate and cultivate students' interest in learning, build up their selfconfidence, form good habits and develop the ability of independent learning and cooperation spirit. Game teaching method can greatly increase children's interest in learning. At the same time, the sense of achievement in the game can also make children's confidence to be established.

Through the communication and cooperation with peers in the game, children's language communication ability and cooperation consciousness can achieve great development. Gamification teaching has great positive significance and important value for the realization of specific teaching objectives.

\subsection{Future Trend of Research on Classroom Game Teaching Method for Children's Second Language Acquisition}

With the development of society and the change of educational concept, education has changed from traditional education to quality education. Nowadays, kindergartens advocate edutainment, which requires children to learn necessary knowledge and ability while playing games happily.

With the deepening of the research on educational games, the following problems will occur in educational games in teaching application, effect research, evaluation management and other aspects. In the aspect of teaching application, the combination of games and knowledge is emphasized. [14] There are very few research documents and practical applications on the combination of educational games and specific subjects in teaching and learning, and even fewer on the combination of educational games and basic education subject teaching.

Therefore, strengthening the integration of educational games and subject teaching or learning should become one of the important concerns of future research. In terms of teaching effect, how to improve the teaching level of teachers using games, how to use games to improve the initiative of learners so as to stimulate learning motivation and improve teaching performance. In the evaluation of management, in the core journals in recent years, in addition to the application of the problems existing in the process of education game are discussed, the evaluation research of education game is almost zero, good teaching must after continuous evaluation, modify, and then to improve such a process, the education game applied in the assessment of teaching is no exception. How to realize the transformation from "electronic game" to "educational game", solve the problem of addiction to games and realize the educational value of games should also be paid enough attention.

\subsection{Prospect of Extensive Application of Game Teaching Method in Children's Second Language Acquisition Classroom}

We can see that the game teaching method has important value, and it will have a broad application prospect in the future. In recent years, mobile Internet has brought tremendous influence to all fields of society. In education, mobile technology is also widely used, and electronic devices are entering the classroom. 
Mobile learning and game teaching are closely related, and can bring revolutionary changes to children's second language learning if properly used. ${ }^{\left[15^{3}\right.}$ By combining game teaching with STEM teaching and VR/AR, through continuous practice and theoretical improvement, game-based learning will surely shine in the field of children's second foreign language teaching. STEM teaching has also received a lot of attention recently. In fact, gamified learning has been playing an important role in STEM teaching, such as MIT's Scratch platform, which has been used in many STEM courses.

VR/AR technology is also promising in education. For example, some schools use VR to learn about planets, and the effect is much better than just looking at pictures and videos. In addition, there are a lot of interesting wearable devices or intelligent agents that can make gamification more interesting and educational.

\section{REFERENCES}

[1] S. Barzilai, I. Blau, Scaffolding game-based learning: Impact on learning achievements, perceived learning, and game experiences, Computers and Education, 70 (2014) 65-79.

[2] Rezaee, A. dan Azizi, Z.2012. The Role of Zone of Proximal Development in The Students' Learning of English Adverbs. Journal of Language Teaching and Research, 3 (1): 51-57

[3] Lin, X. D, et al. Toward Teachers' Adaptive Meta Cognition[J]. Educational Psychologist, 2005, (4).

[4] Admiraal, W., Huizenga, J., Akkerman, S., \& Dam, G. t. (2011). The concept of flow in collaborative game-based learning. Computers in Human Behaviour, 27(3), 1185-1194.

[5] Lin, X. D., Schwartz, D. Reflection at the Crossroad of Cultures[J]. Mind, Culture \& Activities, 2003, (1).

[6] McGonigal, J. (2011). Reality is broken: Why games make us better and how they can change the world. New York, NY, US: Penguin Press.

[7] Deater-Deckard, K., Chang, M., \& Evans, M. E. (2013). Engagement states and learning from educational games. New Directions for Child and Adolescent Development, 2013(139), 21-30.

[8] Boekaerts, M., et al. Goal-directed Behaviour and Contextual Factors in the Classroom: An Innovative Approach to the Study of Multiple Goals[J]. Educational Psychologist, 2006, (1).

[9] Covington, M. V. Goal Theory, Motivation, and School Achievement: An Integrative Review[J]. Annual Review of Psychology ,2000, (1).
[10] Veenman, M. V. J. (2011). Learning to selfmonitor and self-regulate. In R.E. Mayer \& P. A. Alexander (Eds.), Handbook of research on learning and instruction (pp. 197-218). New York, NY: Routledge

[11] Kiili, K. (2005a). Content creation challenges and flow experience in educational games: The itemperor case. The Internet and Higher Education, 8(3), 183-198.

[12] Locke, E. A. \& Latham, G. P. Building a Practically Useful Theory of Goal Setting and Task Motivation: A 35- -year Odyssey[J].American Psychologist ,2002, (9).

[13] Inal, Y., \& Cagiltay, K. (2007). Flow experiences of children in an interactive social game environment. British Journal of Educational Technology, 38(3), 455-464.

[14] Day, S. B., \&Goldstone, R. L. (2012). The import of knowledge export: Connecting findings and theories of transfer of learning. Educational Psychologist, 47(3), 153-176.

[15] Brockmyer, J. H., Fox, C. M., Curtiss, K. A., McBroom, E., Burkhart, K. M., \& Pidruzny, J. N. (2009). The development of the game engagement questionnaire: A measure of engagement in video game-playing. Journal of Experimental Social Psychology, 45(4), 624-634. 